\title{
Energy resources of the South Caucasus Region: the political and security dimensions
}

UDC 327

DOI https://doi.org/10.24195/2414-96162019-5-54-58

Pashaieva Kseniia Faikivna

PhD Student at the Department of International Relations

Odessa I.I. Mechnikov National University

French Blvd., 24/26, Odessa, Ukraine

\begin{abstract}
Vast energy resources and geographic location of the South Caucasus region between the Middle East, Europe and the Russian Federation dictate its complexity. The development of regional energy sectors is influenced by the competition between energy producing and consuming markets aimed at the control over energy routes. Regional energy resources are an important driver for the European engagement in the region, especially due to the EU's need for diversification of energy supplies in the context of its dependence on Russian supplies. The aim of the article is to study development of energy sectors of postsoviet Azerbaijan, Armenia and Georgia at the beginning of XXI century. Also, the growing challenges faced by the South Caucasian countries in the field of energy security are examined. In order to conduct the research comparative method, statistical and case-study approaches were applied.

The article comprises the analyzes of factors undermining the potential of energy sources as a regional economic and political cooperation driver.Protracted conflicts, distrust, spoiled interstate political relations and countries' political instability are major obstacles to cooperation. The complexity of situation is also dictated by different interests and strategies of the main external actors, namely the EU and Russia. Such issues as sustainable energy supply, energy efficiency and the renewable energy resources are also relevant to the region. Consequently, in order to develop the transit potential of South Caucasus it is necessary to resolve vital stability and future development issues, what implies democratic political transformation and multilateral cooperation between the energy producing, consuming, and transit countries. Thus, there is a need to overcome the geopolitical fragmentation of the South Caucasus and establish legal, institutional, political and economic framework for the development of regional energy sectors.

Key words: South Caucasus, energy, security, renewables, European Union.
\end{abstract}

The aim of the article is to study development of energy sectors of post-soviet Azerbaijan, Armenia and Georgia at the beginning of XXI century. We can distinguish the following tasks: 1 ) to analyze regional availability and distribution of energy resources; 2) to examine relations between energy producing and energy consuming countries; 3 ) to studyinfluence of the European Union and Russia on the development of region's energy field; 4) to address the issue of regional energy security and development of renewable energy. The article examines the development of the South Caucasian countries' energy sectors utilizing the comparative method - understood as the comparison of Azerbaijani, Armenian and Georgian energy systems' cases, focusing specifically on its relation to statistical and case-study approaches. The article is expected to enable comparatively-oriented researchers to explore energy issues simultaneously on both the political dimension and security dimension, avoiding thus loss of information about the impact of energy on the region within international relations.

Caucasus is the region reach in energy resources, and which can serve as a bridge between the East and the West. However, due to its geographic location between the Middle East, Europe and Russia region turned to be the geopolitical battlefield, what is not only an issue of geography, but also an issue of struggle between energy producing and consuming markets in order to control the energy supply routes. Geopolitical competition takes place between regional actors, as Armenia and Azerbaijan and international actors, such as Russia, Turkey, Iran competing with each other along with the United States and the European Union.

The political and economic development of the regional countries after the breakup of the Soviet Union can be characterized by the number of fissures, such as the rise of nationalistic ideologies, territorial fragmentation as a result of ethnic and territorial conflicts, social and economic fragmentation of the societies, political and economic instability and distancing from democracy in countries' political development etc [13].

Energy systems and infrastructures of Georgia, Armenia and Azerbaijan were designed to be regional integrated power system within the Soviet energy system. Armenia's nuclear power plant delivered the base load, Azerbaijan supplied the fossilfired medium-load and hydropower plants of Georgia were available for peak-load supply [12]. The dissolution of the Soviet Union resulted in disintegration of the integrated energy system and countries' economies. Moreover, the Nagorno-Karabakh conflict and internal conflicts in the 1990s led to political instability in all three states. The countries faced a need not only to secure and stabilize their energy supplies, but also to determine which regional economic space they wanted to enter.

Azerbaijan as an energy producing country, and Georgia as an energy transit country decided to enter the western economic and energy space. Thus, they started to play vital roles in the European energy diversification projects. However, there is number 
of challenges to Caucasian regional security, explaining risks associated with the operation of energy corridors, especially after the Russia-Georgia conflict in 2008 , provoked by Russia's unwillingness to lose its former sphere of influence [2, p. 233]. Russia's conflict with Georgia and unilateral recognition of Abkhazia and South Ossetia were a try to cut off Georgia, Azerbaijan and Central Asian countries from the European energy projects and influencein order to control all the energy supplies to Europe and to strengthen its positions in the region. On the contrary, Armenia due to its complicated relations with Turkey and Azerbaijan, found itself completely cut off the European energy projects and entirely relies on energy resources coming from Russia.

That is why the issues of energy security are of current concern for the countries of the South Caucasuswhich Benjamin K. Sovacool defines as "an equitable provision of available, affordable, reliable, efficient, environmentally benign, proactively governed and socially acceptable energy services to end-users" [17, p. 150]. Also, an energy security in case of the South Caucasus due to existence of protracted conflicts can be regarded as an issue of hard security. David Turn and Joseph S. Nye mention three basic threats to energy security, such as "the physical disruption of oil supplies, economic and political damage from rapid increases in oil prices, and foreign policyconsequences of energy vulnerability" what is also applicable to the South Caucasus [6, p. 391].

Such issues as sustainable energy supply,the rational use of energy resources (energy efficiency) and the use of renewable energy resources, which are vital for reduction of the impact of fossil fuel energy consumption and climate change are also relevant to the region as are underdeveloped. The main reason for that islack of legal, institutional, political and economic frameworks for the development of substantial energy efficiency and renewable energies potentials $[12$, p. 18].

All three countries have substantial hydropower and other renewable energy potential, but differ widely in fossil energy resources. Armenia does not possess fossil fuels and relies heavily on imports. Energy imports of Georgia are less significant and prices are lower because of in-kind payments for pipeline transit. In contrast, Azerbaijan has significant reserves of both oil and gas [12, p. 14].

Armenia is the only country of the region which has developed legal and economic frameworks for renewable energy.While Georgia has not done it, leaving all responsibility to the market mechanisms. At the same time, there are considerable funds allocated for the development of renewable energy potential of Azerbaijan, which has not been approved by the government [12, p. 15].

Azerbaijan

Azerbaijan has vast reserves of oil and gas. According to the BP Statistical Review of World Energy country's total proved reserves are 7.0 bil- lion barrels of oil and 1,3 trillion cubic meters of gas at the end of 2017 [5]. Moreover, the country has a significant renewable energy potential in the areas of wind, hydro, and biomass.

Economy of Azerbaijan is based largely on the export of oil and gas, that is the reason for little investment in the development of renewables and decreased energy efficiency. However, country's oil and gas resources will be exhausted within the next 20-30 years, which has led to the formulation of a State Program on the use of alternative and renewable energy for 2005-2013, but without the introduction of legislation supporting this goal $[9$, p. 10].

The state is the major stakeholder in Azerbaijan's energy sector, with multiple institutional mechanisms controlling and supervising the domestic energy market of oil and gas exploitation. Despite that, practically the main institution is the State Oil Company of the Azerbaijan Republic (SOCAR), which is a major shareholder in the internationally-led stream projects and is closely tied with the president [3, p. 13].

One of the main issues concerning the security of supplies are physical threats to the transit system, such as terrorist attacks, an escalation of the Nagorno-Karabakh conflict and geopolitical competition in the region, including the war in Ukraine and aggressive policy of Russian Federation towards its neighborhood [3, p. 14].

Energy is a significant source of export revenues and the key driver of country's economy. One can speak about so-called "resource curse" applicable to the case of Azerbaijan. Its vast energy resources and energy export revenues lead to excessive spending and consequent destruction of the national economy [3, p. 15]. That is why diversification plays an important role in the strategic planning of the country, especially in order to ensure its energy security and prevent further economic recession as the reliance on petroleum resources places country at risk of volatility and raises concerns about long-term macroeconomic stability [16].

In 1994 "Contract of the Century" afforded western multinational companies to explore and exploit the Azerbaijan's energy resources. On the basis of the agreement Azerbaijan and Georgia became significant transit states for the Caspian energy resources. Thus, since 1999 the oil from Azerbaijani oilfields flows to the international market through the Baku-Supsa pipeline and since 2006 through the Baku-Tbilisi-Ceyhan pipeline [13, p. 4].

The core of Azerbaijani - European relations is cooperation in economic and energy sectors. Azerbaijan joined the Energy Charter Treaty in 1998 that opened the possibility of cooperation with the EU in the energy sector. This meant that the Europe Union offered Azerbaijan its support for enhancing the production and transportation of oil and gas, and at the same time, it expected from Azerbaijan implementation of the European standards and regu- 
lations within its national legislations. However, lack of progress in country's democratization process, reluctance of government to implement the European policies and regulation standards within the national legislations caused delays in cooperation [13, p. 6].

Disruptions in Russian gas supplies to Europe via Ukrainian pipeline, which occurred in 2006, 2009 and 2014 pushed the EU to the so-called "europianisation" of the energy market aimed at market development in the energy sector through the involvement of third parties. The main goal of the EU's energy security strategy is to diversify the energy supply routes, which would protect the European energy market from geopolitical risks, mainly associated with the use of energy resources as a political tool by the energy producing countries as Russia [13, p. 5].

Thus, in order to create an alternative supply route to Russian pipelines and reserves the European Commission initiated the Southern Gas Corridor - project aimed at development of the necessary infrastructure to transport gas from the Caspian region and the Middle East - primarily Azerbaijan, Iran, Iraq and Turkmenistan to Europe. Azerbaijan has become the key player in the Southern Gas Corridor, both because of gas available for export and its desire to diversify energy exportsfrom Russian streams by developing alternative pipelines directly to Europe.The European Commission's strategic objective of the Southern Gas Corridor is to meet from 10 to $20 \%$ of the EU's gas demand by 2020 [1, p. 3]. Along with the other pipeline projects, such as: Nabucco, the Interconnector TurkeyGreece-Italy (ITGI), the Trans Adriatic Pipeline (TAP) and SEEP (South East European Pipeline) [10, p. 3].

However, it is important to remember about geopolitical location of Azerbaijan which has critical relations with Iran, balances in relations with Russia, and neighbors conflict zones of the South Caucasus - Nagorno-Karabakh, South Ossetia and Abkhazia. The war between Russia and Georgia of 2008 and consequent Russian occupation of South Ossetia and Abkhazia demonstrated the vulnerability of the transit system to Europe and poses challenges to long-term security of the pipeline system. Also, it is so important for Azerbaijan to avoid confrontation with Russia due to existence of issues that can be exploited by Russia, such as escalation of the Nagorno-Karabakh conflict [1, p. 34]. That raises a need for Azerbaijan to balance between Russia, Iran, and Turkey, until the EU has become not only a key economic partner, but an important security partner as well [10, p. 5].

Georgia

According to the U.S. Energy Information Administration Georgia does not possess any crude oil production or proved petroleum reserves. Although, petroleum accounts for the largest share of energy consumed in Georgia, and country is among the top 10 petroleum-consuming states. The country also does not have any natural gas reserves or production contributing to its primary energy supply [8].As a result, Georgia is heavily dependent on energy supplies coming from abroad. Natural gas is imported from Azerbaijan (proceeds from South Caspian Pipeline agreement and direct purchase) and previously from Russia (proceeded from transit of Russian gas to Armenia). Country benefits substantially from the natural gas transit between neighboring countries by obtaining the in-kind fee and the cheap optional gas [12, p. 72].

It is important to mention that the Georgian state does not a play key role in the energy sector, only controls some of the most sensitive of its assets. Electricity, gas distribution, hydro and thermal power plants are privatized or owned by foreign energy companies [3, p. 17].

Georgia is rich in renewable energy resources, namely small hydro, wind, geothermal and solar power. However, only a very small part of the potential is being exploited. Renewable resources fuel almost one-tenth of Georgia's net electricity generation, about half of that generation comes from biomass. In 2017 Georgia became third after California and Florida, in the amount of energy generation from biomass resources [8]. The rest of Georgia's generation from renewable resources is provided by hydroelectricity or solar photovoltaics. Georgia possesses vast hydro resources that account for $17 \%$ of its energy supplies and $80 \%$ of its electricity generation [3, p. 17].

In 2007 the Georgian government declared its interest in development of renewables, namely in construction of small hydro power plants and wind farms. State Policy in the Energy Sector was adopted by the parliament in 2006, and declared as Georgia's long-term objective the need to meet demand for electricity by its own hydro resources. However, the lack of a clear state strategy, absence of action plan for renewable energy development and legislative vacuum have not led to any practical results [9, p. 11].

Georgia is the main transit country for resources from Azerbaijan to Europe.The British Petroleum Company has been operating energy transit projects in Georgia for 19 years and is the lead investor and operator of Baku-Tbilisi-Ceyhan (BTC) pipeline, South Caucasus gas Pipeline (SCP) and Western Route Export Pipeline (Baku-Supsa pipeline) [7].

Thus, involvement in the European market, further diversification of energy sources and transportation routesareseen in Georgia as a best way to ensure its energy security, which is according to the National Security Concept is a key component of national security and a basic national interest [11]. Georgia is not self-sufficient as Azerbaijan and is not like Russia-dependent Armenia, having deadlocked relations with Russia [13, p. 2]. That is the one of the main reasons for Georgian higher degree of determination to democratization and implementation ofthe European norms [13, p. 2]. Moreover, transportation of energy resources through country's territory is seen as a way of attracting interest of the Western partners, what can positively influence political stability and security. 
Along with that, Georgia due to its intensified relations with the West is now under greater threat from Russia, than Armenia and Azerbaijan [15, p. 2]. The impact of unresolved conflicts in Abkhazia and South Ossetia are seen as a key hindering factor forthe security of supplies. Due to the fact thatAbkhazian and South Ossetian territories are de facto controlled by Russiawhich can use the threat of supply interruption as a political weapon [3, p. 19].

In 1995 Georgia joined the Energy Charter Treaty. Now it is the only country in the South Caucasus that signed an Association agreement with the EU. Georgia has the status of a candidate in theEuropean Energy Community. Membership in the Community establishes versatile cooperation with the EU and other countries in the energy field, and can provide Georgia with energy security and positively influence its political and economic development. Nowcountry cooperates with the EU in the energy sectorwithin thebilateral form, as part of the Association Agreement. The EU supports the strengthening of Georgia's energy security, which stands for bringing national legislation closer to the European one, and developing cooperation in fields of electrical power, renewable energy, energy efficiency, exploration, extraction and transportation of natural gas and oil $[13$, p. 6]. However, the result of this process depends on the country's democratization and political stability.

\section{Armenia}

According to the International Trade Administration Armenia has limited energy resources and can meet only $35 \%$ of demand for energy from domestic resources [4]. It does not possess confirmed oil and natural gas reserves, and is highly dependent on the import of energy resources. Oil and oil products are imported from Georgia, Iran, Russia and Europe, while natural gas and nuclear fuel are imported from Russia, along with smaller volumes of Iranian gas, which are swapped for electricity [4]. Moreover, Armenian level of energy efficiency is low. Country is completely dependent on Russian nuclear fuel, which is used to generate about one third of the country's electricity at Armenia's single nuclear power plant in Metsamor [3, p. 8].

Armenia is not a transit country for oil and gas. Its energy sector faces such challenges as supply gap, absence of energy supply reliability, and the need to maintain affordable tariffs. That is the reason for adaptation of several laws focused on development of renewable energy resources and implementation of energy efficiency measures by government.

The National Security Strategy of Armenia states that energy dependence is one of the main security threats, placing burden on the balance of payments [14]. Along with energy supplies, which are vulnerable to technical accidents, natural disasters, growing instability in the conflict region, and unfriendly policy of neighboring states [3, p. 9]. In order to ease energy dependence, the Armenian government seeks to diversify energy suppliesto become independent from energy imports from Russia and Iran, and to develop sustainable and reliable export-oriented energy system, as well as, to ensure its security and affordable power supply.

In 1998 Armenia became a member of the Energy Charter Treaty. Butit does not function as a transit route country and did not manage to be involved in the construction of the European energy projects. Due to its heavy reliance on energy supplies from Russia, which is geopolitical rivalry of the EU in the region $[13$, p. 2]. Russia uses tension between Armenia and Azerbaijan around the issue of the unresolved Nagorno-Karabakh conflict as a tool, keeping Armenia in its sphere of influence. Also, there are no diplomatic relations between Armenia and Turkey, which is along with Azerbaijan are key players in development of the European energy structure,cutting Armenia off the possibility to become involved in the Caspian energy resources transportation [13].

As a result of increased pressure from Russia, Armenia abandoned the Association agreement in 2013 and joined the Russian-led Eurasian Economic Union, established as a geopolitical counterbalance to the European influence in the region. Thus, Armenia's integration with the EU has become stalled [15, p. 2].

\section{Conclusion}

All things considered, the transit potential of South Caucasus can play an important role in bringing the Caspian energy resources to the global market. In order to reach this goal it is necessary to resolve vital stability and future development issues, what implies democratic political transformation and multilateral cooperation between the energy producing, consuming, and transit countries.

Territorial conflicts, mutual fears, mistrust and spoiled interstate relationsserve as major obstacles to cooperation. This situation is aggravated by the external actors, namely the EU and Russia, pursuing their own interests and strategies in the region. Russia strives to keep its dominant position and control over energy supplies toEurope. The EU encourages the promotion of regional cooperation, liberal market economy and democratic governance, as well as, is interested in access to the Caspian energy resources to reduce its dependence on Russia's supplies. Thus, there is geopolitical fragmentation of the South Caucasus, impeding interdependent energy security strategies.

Also, all three countries of the region have different vectors of development of their energy sectors. Armenia did not renounce its nuclear power plant and sees inthe construction of a new nuclear reactor a way to its energy independence. Georgia plans to maximize use of hydro resources, and Azerbaijan tries toget an access to a new energy markets for the export of its natural gas and oil.

Moreover, it is important for the regional countries to develop their renewable energy potentials, as it can provide them with energy supply and operate in autonomous networks directly meeting the demand of local energy markets more quickly than traditional energy sources. 


\section{REFERENCES:}

1. Armenia - Energy Sector. URL: https://www. export.gov/article?id=Armenia-energy-sector [in English].

2. Georgia - Oil and Gas. URL: https://www.export. gov/article?id=Georgia-Oil-and-Gas [in English].

3. Georgia. State Profile and Energy Estimates. URL: https://www.eia.gov/state/analysis.php?sid=GA [in English].

4. National Security Concept of Georgia. URL: https://mod.gov.ge/uploads/2018/pdf/NSC-ENG.pdf [in English].

5. Republic of Armenia National Security Strategy. URL: https://www.mfa.am/filemanager/Statics/Doctrineeng.pdf [in English].

6. Abbasov, S. (2014). Azerbaijan Could Benefit from Russia-Ukraine Crisis but Risks Are High. Investor. ge, № 39, pp. 2-36 [in English].

7. Abolhosseini, S., Almas H., Rashidghalam M. (2017). Energy Security and Competition over Energy Resources in Iran and Caucasus Region. AIMS Energy 5 , № 2, pp. 224-238 [in English].

8. Alieva, L., Shapovalova N. (2015). Energy Security in the South Caucasus: Views from the Region. CASCADE. URL: http://www.cascade-caucasus.eu/ wp-content/uploads/2015/12/CASCADE-D8.3Workingpaper-Energy-Security.pdf [in English].

9. BP Statistical Review of World Energy 2018. Report. 67th ed. URL: https://www.bp.com/content/ $\mathrm{dam} / \mathrm{bp} / \mathrm{businesssites/en/global/corporate/pdfs/energy-}$ economics/statistical-review/bp-stats-review-2018-fullreport.pdf [in English].

10. Deese, D.A., Nye J.S. (1981). Energy and Security. Cambridge, Mass: Ballinger Pub [in English].
11. Kochladze, M. (2009). South Caucasus Countries Can Benefit from Alternative Energy Development. Caucasus Analytical Digest, № 3, pp. 9-12 [in English].

12. Meister, S. (2014). Energy Security in the South Caucasus. The Southern Gas Corridor in Its Geopolitical Environment. DGAPkompakt, № 2, URL: ttps:// www.ssoar.info/ssoar/bitstream/handle/document/ 53659/ssoar-2014Energy_Security_in_the_South. pdf?sequence=1 [in English].

13. Opitz, P. (2015). Sustainable Energy Pathways in the South Caucasus: Opportunities for Development and Political Choices. URL: https://ge.boell.org/ sites/default/ files/book_200x240mm.pdf[in English].

14. Pataraia, T. (2015). Energy Transit and Security Imbalance in South Caucasus: The Road between Russia and the European Union. URL: http://ge.boell.org/ sites/default/files/uploads/2015/03/energy_eng-final_1. pdf [in English].

15. Sarjveladze, M. (2017). The South Caucasus in the Context of the EU-Russia Crisis. Security Policy Working Paper, № 28, URL: https://www.baks.bund.de/ sites/baks010/files/working_paper_2017_28.pdf [in English].

16. Siddi, M. (2017). The Southern Gas Corridor: Challengesto a GeopoliticalApproachinthe EU's External Energy Policy. FIIA Briefing Paper, № 216, URL: https://www.31673541/The Southern_Gas_Corridor Challenges_to _a_geopolitical_approach_in_the_EUs_ external_energy_policy [in English].

17. Sovacool, B.K. (2013). An International Assessment of Energy Security Performance. Ecological Economics, № 88, pp. 148-158 [in English].

\section{Енергетичні ресурси Південного Кавказу: політичний і безпековий виміри}

\section{Пашаєва Ксенія Фаіківна}

аспірант кафредри міжнародних відносин

Одеського національного університету імені І.І. Мечникова

Французький бул., 24/26,

Одеса, Україна
Актуальність дослідження зумовлена роллю, яку відіграють енергетичні ресурси у регіональних процесах на Південному Кавказі, враховуючи його географфічне положення між Близьким Сходом, Європою та Російською федерацією. Енергетичні сектори країн регіону розвиваються під впливом конкуренції за контроль над енергетичними маршрутами на ринку виробників і споживачів енергетичних ресурсів. Енергетичні ресурси регіону є фрактором європейської залученості до регіону, особливо у зв'язку з потребою ЄС у диверсифікації енергетичних поставок у контексті його залежності від російських. Метою статті є вивчення розвитку енергетичних секторів пострадянських Азербайджану, Вірменії та Грузії на початку XXI cm. Також вивчаються виклики енергетичній безпеці країн Південного Кавказу. Питання енергетичної безпеки є вкрай важливими для трьох країн Південного Кавказу та ЄС. Для аналізу розподілу енергоресурсів у регіоні, вивчення відносин між країнамивиробниками та країнами-споживачами, аналізу впливу ЄС і Росії та дослідження питання регіональної енергетичної безпеки та розвитку відновлюваної енергії було використано компаративний, кейс і статистичний методи.

Основним результатом статті $\epsilon$ аналіз факторів, які підривають потенціал енергоресурсів як основи для економічної та політичної співпраці в регіоні. Територіальні конфрлікти, недовіра, складні політичні відносини між країнами регіону та політична нестабільність кожної країни окремо $є$ головними перешкодами на шляху до кооперації. Складність ситуації також пояснюється різними інтересами та стратегіями провідних міжнародних акторів, а саме ЄС та Росії. Такі питання, як стабільне енергопостачання, єфективне використання енергоресурсів і розвиток відновлюваних джерел енергії також $є$ актуальними для регіону. Таким чином, для розвитку енергетичного та транзитного потенціалу Південного Кавказу необхідно забезпечити стабільність і можливості для майбутнього розвитку, що передбачає демократичну політичну трансформацію та багатосторонню співпрачю між країнами, що виробляють, споживають і транспортують енергоресурси. Головним завданням на цьому шляху є подолання геополітичної фррагментації Південного Кавказу та розробка правових, інституційних, політичних та економічних рамок задля майбутнього розвитку систем регіональної енергетики.

Ключові слова: Південний Кавказ, енергетика, безпека, поновлювані джерела енергії, Європейський Союз. 